\title{
Note
}

\section{T-cell-rich B-cell lymphoma in a dog}

\author{
Kenji Rimpo $^{1)}$, Yumiko Kagawa ${ }^{2)}$, Tetsushi Yamagami ${ }^{3)}$
}

\begin{abstract}
A 6-year-old castrated male Labrador Retriever was presented with lymphadenopathy of the right submandibular lymph node. Abdominal ultrasound revealed a hypoechoic splenic mass and sublumbar lymphadenopathy. The right submandibular lymph node lesion was identified as T-cell-rich B-cell lymphoma, characterized by a mixed cell population with large neoplastic B cells (CD20 and CD79a positive) scattered among numerous small non-neoplastic T cells (CD3 positive) and histiocytes (CD18, MHC class II and Iba1 positive). Cytologic evaluation showed tumor cells invading into the spleen and intra-abdominal lymph nodes. The dog received chemotherapy, but it did not respond sufficiently to the treatment and died $\mathbf{5 4}$ days after the initial presentation.
\end{abstract}

Key word : dog, immunohistochemistry, T-cell-rich B-cell lymphoma

T-cell-rich B-cell lymphoma (TCRBCL) is a histologic subtype of diffuse B-cell lymphoma. This tumor is characterized by a mixed cell population with large neoplastic B cells scattered among numerous small non-neoplastic T cells. The neoplastic B lymphocytes typically constitute $5-20 \%$ of the total cell population $[1,11]$. In veterinary medicine, a limited number of cases of TCRBCL have been reported. TCRBCL was initially reported in a human patient in 1984 [5], followed by other species including the horse, pig, cat, dog, and ring-tailed lemur $[1,2,4,6,7,9,10,12]$. This atypical lymphoma is most commonly seen in horses (35\%) and cats (7\%), but constitutes only $2-3 \%$ of the lymphomas found in the cow, dog, and pig [11].

Vezzali et al. reported only one case of TCRBCL in 123 dogs with lymphoma [12]. Aquino et al. also reported a case of orbital TCRBCL in a $\operatorname{dog}[1]$. This dog responded well to chemotherapy initially but was euthanized because of neoplastic recurrence in 6 months. At the time of the recurrence, the neoplastic cell population was consistent with the cell population seen in diffuse lymphoblastic B-cell lymphoma (DLBCL). No details of the chemotherapeutic protocol were reported. Here, we present a case of TCRBCL in a dog.

A 6-year-old castrated male Labrador retriever was referred to Saitama Veterinary Medical Center for further evaluation of right submandibular lymph node enlargement. Physical examination revealed firm, enlarged lymph nodes (right submandibular : $3.0 \times 3.0 \times 2.5 \mathrm{~cm}$; left subscapular : $3.5 \times 3.0 \times 3.0 \mathrm{~cm}$; right popliteal : $2.0 \times 1.8 \times 1.5 \mathrm{~cm} ;$ left popliteal: $2.0 \times 1.5 \times 1.5 \mathrm{~cm})$. Other physical examination findings were unremarkable. Complete blood count $(\mathrm{CBC})$ and blood chemistry profile showed thrombocytopenia $\left(102 \times 10^{3}\right.$ cells $\left./ \mu \mathrm{L}\right)$. The $\mathrm{C}-$ reactive protein level was elevated $(15$ $\mathrm{mg} / \mathrm{dL}$ ). Prothrombin time (PT), activated partial thromboplastin time (APTT), fibrin/fibrinogen degradation products (FDP), and antithrombin (AT) activity were normal. Abdominal ultrasound revealed mild splenomegaly with diffuse heterogeneous echogenicity and sublumbar lymphadenopathy $(4.6 \times 2.9 \times 2.7 \mathrm{~cm})$.

Cytologic evaluation of aspirates from the right submandibular and left superficial cervical lymph nodes revealed a mixed population of mature lymphocytes, prolymphocytes, and blasts. The majority of the sample was composed of rela-

1) Saitama Animal Medical Center, 7-2-7 Azuma-cho, Iruma-shi, Saitama 358-0002, Japan

2) North Labo, 8-35-2 Kita, Hondoori, Shiraishi-ku, Sapporo 003-0027, Japan

3) Marupi Lifetech Co. Ltd., 103 Fushio-cho, Ikeda-shi, Osaka 563-0011, Japan

Corresponding author : Kenji Rimpo Telephone : 042-966-1031 Facsimile : 042-966-3773 Email address : rinpou@bh.wakwak.com

Received : April 9, 2012 / Accepted : November 14, 2012 


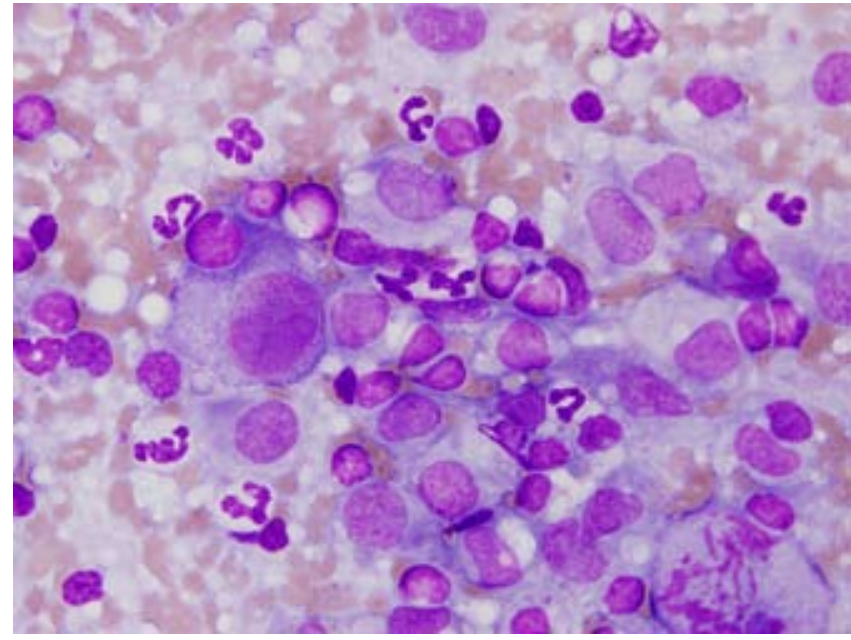

Fig. 1. Aspirates from the right submandibular lymph node $(\times 1,000)$. The obtained mononuclear cells contained mildly basophilic cytoplasm and nuclei with a coarse chromatin pattern. The morphology of these cells was consistent with dysplastic lymphoid blast cells or histiocytes.

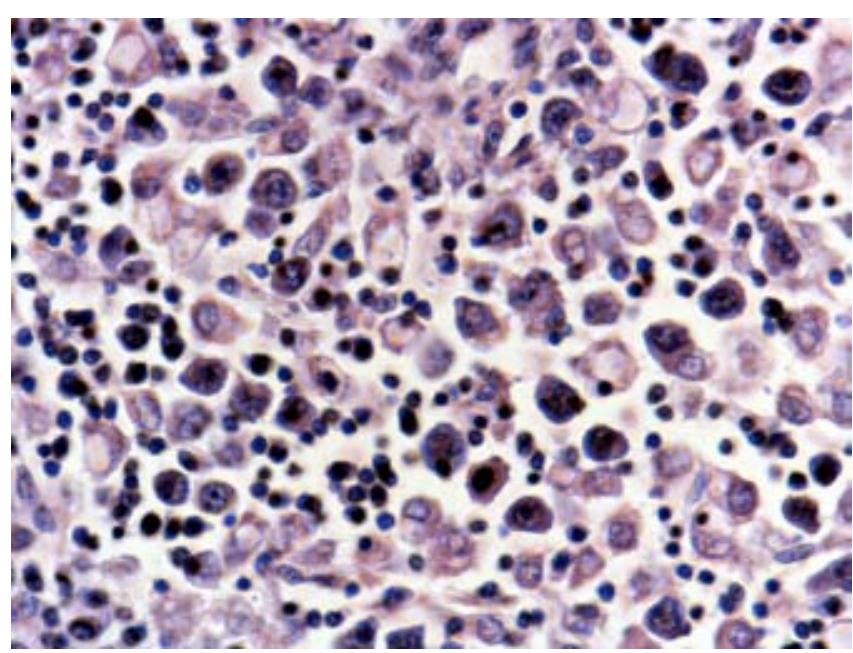

Fig. 2. Right submandibular lymph node (hematoxylin-eosin stain, $\times 400)$.

Large neoplastic cells with dyskaryosis and large nucleoli, small lymphocytes, and mononuclear cells with pale nuclei and abundant cytoplasm were seen.

tively unaltered mature lymphocytes, and the blast percentage did not appear to exceed the level of reactive hyperplasia. However, most of the lymphocytic cells were large and had severe nuclear atypia such as enlarged nuclei and multinucleation (Fig. 1). For further evaluation of the lymphadenopathy and thrombocytopenia, excisional biopsies of the right submandibular lymph node, liver, and spleen, and cytologic examinations of aspirates from the sublumbar lymph nodes and bone marrow were performed 7 days after the initial presentation. Cytologic evaluations of the spleen and sublumbar lymph nodes revealed a mixture of small lymphocytes and intermediate-to-large round cells. The intermediate-to-large round cells had broad basophilic cytoplasm and large nuclei with a faint chromatin pattern. These cells also had anisokaryosis, multiple nuclei, and/or other prominent nuclear atypia. Aspirates from the liver revealed the presence of lymphocytes and histiocytes with nuclear atypia, and mild vacuolar change in hepatocytes. Histologic examination of the right submandibular lymph node showed that most of the normal structure of the lymph node was lost, and that the sample was composed of sheets of large round cells and small lymphocytes. These large round cells had relatively abundant eosinophilic cytoplasm and large, irregular nuclei, which had finely stippled chromatin and clear nucleoli. Neoplastic cells were moderately variable in size, and multinucleated cells or dysplastic cells were also seen. Ten $400 \times$ fields showed three to 10 mitotic figures (Fig. 2).

To determine the origin of the neoplastic cells, with histiocytic sarcoma or atypical lymphoma being the likely sources, immunohistochemical analyses were performed. The large neoplastic cell population with nuclear atypia was positive for CD20 (Thermo Scientific, CA, USA), CD79a (Dako Cytomation, CA, USA), and Ki-67 (Zymed Laboratories, CA, USA). Other cells with abundant cytoplasm and relatively pale nuclei were positive for CD18 (Dr. P. F. Moore, University of California Davis, CA, USA) and MHC class II (HILA-DR Antigen, Alpha-chain) (Dako Cytomation, CA, USA) and Iba-1 (Wako, Osaka, Japan, but negative for Ki-67. The small round cells were positive for CD3 (Dako Cytomation) (Fig. 3). On the basis of these findings, the origin of the neoplastic cell population was considered to be B cells, with normal T-cell and histiocytic populations intermingled in the sample. These findings were consistent with TCRBCL. Bone marrow aspirates did not present any abnormalities.

The patient received lomustine (CCNU;80 mg $/ \mathrm{m}^{2}$, PO, every 3 weeks) starting from 16 days after the initial presentation. Owing to the patient's poor response to the treatment, L-asparaginase injections (10,000 IU/dog, SC) were administered 38 and 46 days after the initial presentation. Despite a partial response to the chemotherapy, the dog died 54 days after the initial presentation. Although the lymph nodes appeared to have decreased in size, thrombocytopenia $\left(27 \times 10^{3}\right.$ cells $/ \mu \mathrm{L})$ and a decrease in AT activity to $69 \%$ were noted at the end of the treatment. 

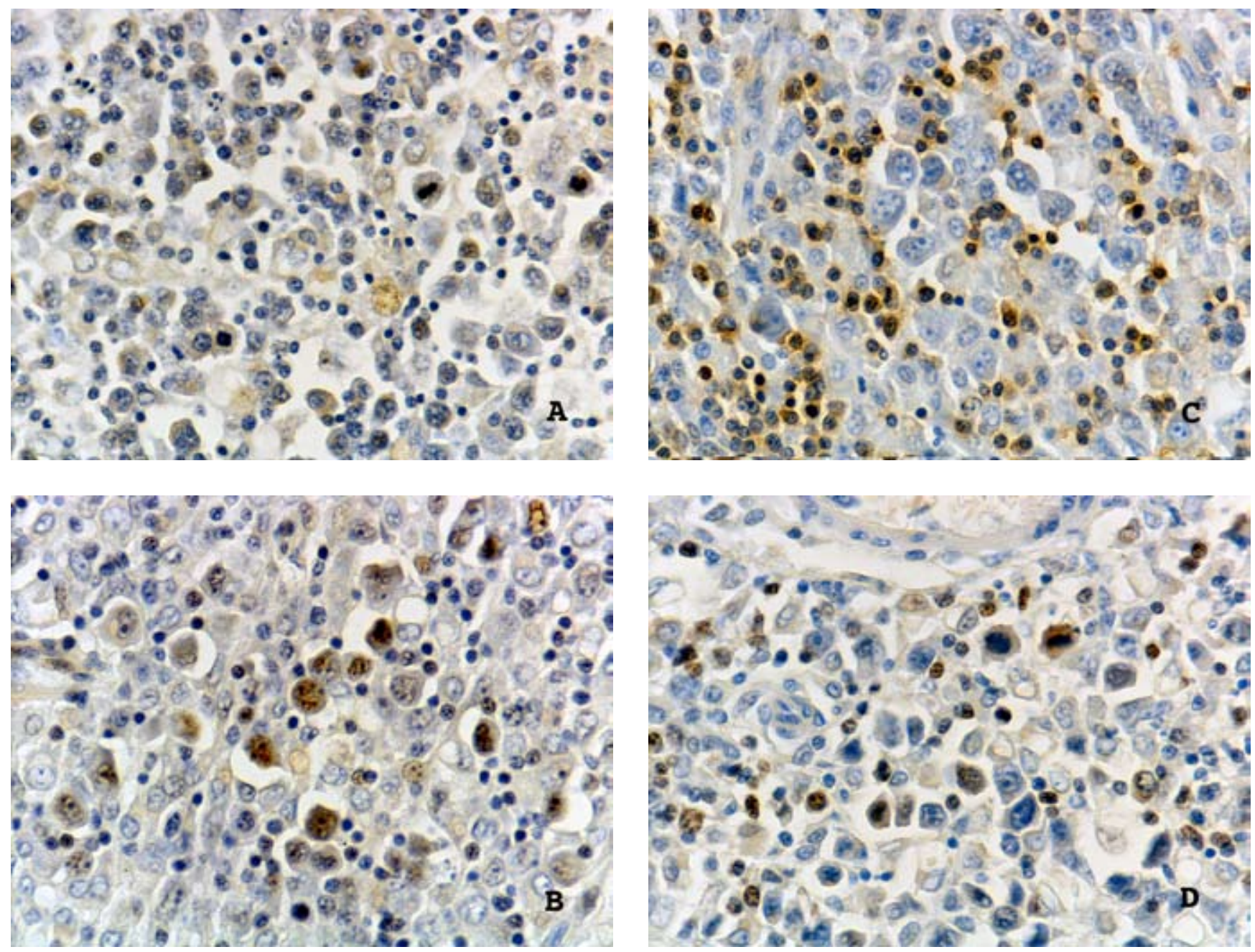

Fig. 3. Immunohistochemistry of right submandibular lymph node $(\times 400)$.

Large dysplastic cells were positively stained for CD20 (Fig. 3A) and CD79a (Fig. 3B). The small lymphocytes were positive for CD3 (Fig .3C). Many of the large atypical cells were Ki-67 positive (Fig. 3D).

Canine lymphoma is often diagnosed according to the Updated Kiel Classification System (UKCS) [3], and a high-grade lymphoma can be diagnosed cytologically on the basis of a characteristic, homogeneous, large, atypical, immature lymphocytic population. However, histologic evaluation is warranted in cases with inconclusive cytologic features, such as a lowgrade lymphoma, early stage of high-grade lymphoma, and mixed-cell tumors including TCRBCL.

The case reported herein was initially suspected to be a histiocytic sarcoma on the basis of the initial cytologic evaluation of the aspirates. Further investigations, including excisional biopsy with hematoxylin-eosin (HE) staining and immunohistochemistry, were required for a definitive diagnosis. Routine histologic evaluation only with HE staining often allows definitive diagnosis of atypical lymphomas. However, additional diagnostic tests, including various immunohistochemical analyses, may be required in order to diagnose atypical lymphomas such as TCRBCL.

Because the large atypical cells were positive for both CD20 and CD79a, we concluded they were of B cell origin. Although relatively few atypical cells were identified as B cells, we classified their proliferation as neoplastic, because they were positive for $\mathrm{Ki}-67$, a proliferation marker. The cells with relatively pale nuclei and abundant cytoplasm were positive for CD18, MHC class II and Iba-1 and were therefore considered to be histiocytes. The small round cells that were morphologically characterized as lymphocytes were identified as T cells, because they were positive for CD3. The histiocytes and small $\mathrm{T}$ cells were $\mathrm{Ki}-67$ negative to weakly positive, indicating limited proliferative activity ; accordingly, we indirectly characterized these cells as non-neoplastic.

The aforementioned findings led us to conclude that the tumor was a B-cell lymphoma containing a mixed population of 
T cells and histiocytes. Therefore, we diagnosed the case as TCRBCL according to the WHO classification of animal lymphoma. The diagnosis would have been T-cell/histiocyte-rich lymphoma, if we had employed the WHO classification of human lymphoma, but this term does not exist in the animal lymphoma classification.

Our patient initially received CCNU on the basis of the presumptive diagnosis of histiocytic sarcoma. The patient showed only a partial response to L-asparaginase injections, which supported the diagnosis of TCRBCL. CCNU is an alkylating agent often used for histiocytic sarcomas as an induction agent or for lymphomas as a part of rescue protocols. It is, however, unsuitable for lymphoma as the induction treatment [8]. A multiple drug protocol such as the CHOP protocol may have been suitable for our case.

Our patient also exhibited persistent thrombocytopenia despite unremarkable bone marrow aspiration findings at the initial presentation. At the initial presentation, disseminated intravascular coagulopathy (DIC) was considered less likely because of the normal FDP value and AT activity. Although the exact mechanism of the persistent thrombocytopenia remained unclear, paraneoplastic immune-mediated thrombocytopenia was considered likely.

At present, the biologic behavior and response to various chemotherapeutic protocols of canine TCRBCL are largely unknown. Further investigation of this unusual lymphoma in dogs is strongly warranted.

\section{References}

[1] Aquino S.M., Hamor R.E., Valli V.E., Kitchell B.E., Tunev S.S., Bailey K.L., Ehrhart E.J. (2000) : Progression of an orbital T-cell rich B-cell lymphoma to a B-cell lymphoma in a dog. Vet Pathol. 37 (5) : 465-469.

[2] Day M.J., Kyaw-Tanner M., Silkstone M.A., Lucke V.M., Robinson W.F. (1999) : T-cell-rich B-cell lymphoma in the cat. $J$ Comp Pathol. 120 (2) : 155-167.

[ 3 ] Fournel-Fleury C., Magnol J.P., Bricaire P., Marchal T., Chabanne L., Delverdier A., Bryon P.A., Felman P. (1997) : Cytological and immunological classification of canine malignant lymphomas : comparison with human non-Hodgkin's lymphomas. $J$ Comp Pathol. 117 (1) : 35-59.

[ 4 ] Henson K.L., Alleman A.R., Cutler T.J., Ginn P.E., Kelley L.C. (1998) : Regression of subcutaneous lymphoma following removal of an ovarian granulosatheca cell tumor in a horse. J Am Vet Med Assoc. 212 (9) : 1419-1422.

[ 5 ] Jaffe E.S., Longo D.L., Cossman J., Hsu S.-M., Arnold A., Kors-meyer S.J. (1984) : Diffuse B cell lymphomas with T cell predominance in patients with follicular lymphoma or "pseudo T cell lymphoma." Lab Invest. 50 (1) : 27A-28A.

[6] Kelley L.C., Mahaffey E.A. (1998) : Equine malignant lymphomas : morphologic and immunohistochemical classification. Vet Pathol. 35 (4) : 241-252.

[ 7 ] Pye G.W., Bennett R.A., Terrell S.P., Ginn P.E., McSherry L.J., Alleman A.R. (2000) :T-cell-rich B-cell lymphoma in a ringtailed lemur (Lemur catta). J Zoo Wildl Med. 31 (3) : 388-393.

[8] Sauerbrey M.L., Mullins M.N., Bannink E.O., Van Drop T.E., Kaneene J.B., Obradvich J.E. (2007) : Lomustine and prednisone as a first-line treatment for dogs with multicentric lymphoma : 17 cases (2004-2005). J Am Vet Med Assoc. 230 (12) : 18661869 .

[ 9 ] Steele K.E., Saunders G.K., Coleman G.D. (1997) : T-cell-rich B-cell lymphoma in a cat. Vet Pathol. 34 (1) : 47-49.

[10] Tanimoto T., Ohtsuki Y. (1998) : T-cell-rich B-cell lymphoma in a pig. Vet Pathol. 35 (2) : 147-149.

[11] Valli V.E., Jacobs R.M., Parodi A.L., Vernau W., Moore P.F. (2002) : Histological Classification of Hematopoietic Tumors of Domestic Animals. pp.36-37. In : WHO International Classification of Tumors of Domestic Animals, 2nd. Ed. (Schulman, F.Y. ed.) , Armed Forces Institute of Pathology, Washington, DC, USA.

[12] Vezzali E., Parodi A.L., Marcato P.S., Bettini G. (2009) : Histopathologic classification of 171 cases of canine and feline nonHodgkin lymphoma according to the WHO. Vet Comp Oncol 8 (1) : 38-49. 


\section{T-cell-rich B-cell lymphoma の犬の1例}

林宝謙治 ${ }^{1)}$, 賀川由美子 ${ }^{2)}$, 山上哲史 ${ }^{3)}$

\section{和文要約}

右下買リンパ節の腫脤を主訴に6歳齢、去勢雄のラブラドール・レトリーバーが来院した。腹部エコー検査では脾藏の腫 瘤と腰下リンパ節の腫脹が認められた。右下顎リンパ節は、多数の小型の非腫瘍性 T 細胞（CD3陽性）と組織球（CD18、 MHC class II および Iba-1陽性）に混じて大型の腫瘍性 B 細胞（CD20およびCD79a 陽性）が混合した細胞集団からなり、 これらの特徵により T-cell-rich B-cell lymphoma と確定した。細胞学的評価では、脾臓と腹胿内リンパ節にも腫瘍細胞が 浸潤していた。この犬は化学療法による治療を受けたが、十分な反応が見られず第54病日に死亡した。

Key word : dog, immunohistochemistry, T-cell-rich B-cell lymphoma

1）埼玉動物医療センター $=358-0002$ 埼玉県入間市東町7-2-7

2) ノースラボ $=003-0027$ 札幌市白石区本通2丁目北8-35

3）マルピーライフテック株式会社％563-0011大阪府池田市伏尾町103番地

連絡責任者:林宝謙治 埼玉動物医療センター ３558-0002 埼玉県入間市東町7-2-7 電話：042-966-1031、FAX：042-966-3773

メールアドレス：rinpou@bh.wakwak.com

受付日：2012年4月9日、採択日：2012年11月14日

(c)2013. Japan Veterinary Cancer Society 